\section{International Scientific Journal Theoretical \& Applied Science}

p-ISSN: 2308-4944 (print) e-ISSN: 2409-0085 (online)

Year: $2015 \quad$ Issue: $11 \quad$ Volume: 31

Published: $30.11 .2015 \quad$ http://T-Science.org

\section{Arofat Abdulhamidovna Ismanova \\ Doctoral student \\ The Republic Scientific-Practical \\ Center for National Idea and Ideology \\ Andijan, Uzbekistan \\ conference_2012@list.ru}

SECTION 21. Pedagogy. Psychology. Innovations

in the field of education.

\title{
EDUCATIONAL AND OTHERS TECHNOLOGIES FOR THE PREVENTION OF THE STRUGGLE AGAINST RELIGIOUS EXTREMISM AND TERRORISM
}

\author{
Abstract: In this article, some forms of preventive work with youth on prevention of various kinds of \\ manifestations of the religious extremism and terrorism in the modern society and some technologies for struggle \\ again them are considered. \\ Key words: extremism, terrorism, youth, education, ideology, psychological and pedagogical factors, \\ prevention, national idea. \\ Language: English \\ Citation: Ismanova AA (2015) EDUCATIONAL AND OTHERS TECHNOLOGIES FOR THE \\ PREVENTION OF THE STRUGGLE AGAINST RELIGIOUS EXTREMISM AND TERRORISM. ISJ \\ Theoretical \& Applied Science 11 (31): 63-66. \\ Soi: http://s-o-i.org/1.1/TAS-11-31-11 Doi: crossef http://dx.doi.org/10.15863/TAS.2015.11.31.11
}

Unfortunately, in the modern world the situation is such that the destabilization of the political situation in the society has led to the proliferation and growing influence of religious extremism and terrorism. Experience shows that the struggle against these manifestations of the evil only by military effort is not effective. Therefore, it is necessary to put at the forefront of combating religious extremism and terrorism with the use of pedagogical, ideological, and other technologies to prevent their manifestation in real life.

Without the work on the ideological front there is no opportunity to expect success in the fight against the extremism and terrorism. Therefore, it is necessary to lead the competent, gentle, but persistent work with the media. It is needed to put on a stream creation of professional documentaries, broadcasts, articles, roundtables and conferences that exposed the misanthropic essence of the extremism and terrorism in all its manifestations, primarily religious and political. Also it is necessary to promote in various ways the hopelessness offered by the extremists of the way, their backwardness, scarcity, squalor, crime goals, means and methods of activity.

We cannot let to the extremists and terrorists and their leaders access to media. It is needed the tightening of legislative measures that must be directed at the prohibition (or restriction) of covering the activity of the extremists and terrorists and their leaders. Nothing new they can say no. The reference to the fact that they, supposedly, have to resort to terrorist acts to the government and society have their voices heard, are groundless and vicious. Humanity produces enough forms, methods and norms to a particular worker or a group of people expressed their interests in a civilized way. If someone prefers to speak with the state and society the language of hostage-taking, acts of terrorism, the answer must be one - the merciless destruction.

There is necessary special regime of media access to information in the case of the bandit's new terrorist attacks. This mode means the imposition of reasonable restrictions on the coverage of the terrorist attack:

- first, in order not to interfere with the work of the special services;

- secondly, not to create for extremists and terrorists advertising that they're doing in the first place;

- third, in order not to escalate the tantrum and do not bring people to watch television infarct state.

With the help of the mass-media have to constantly convince people and facts to prove that truth is on our side, our cause is just and victory will be ours.

It is needed to work hard with the representatives of the traditional Islam, demand from 
them active position, involve them in the ranks of the fighters against the religious and political extremism.

In preventing of the religious-political extremism and terrorism should highlight the main directions and priorities of scientific research. There are main directions: philosophical and religious, political and socio-economic, management, communicative, philological, psychological and social-psychological, criminological, pedagogical, cultural, medical-biological, information and communication technologies and bases for the prevention of the religious and political extremism and terrorism.

There are some priority problems. The philosophical and religious bases for the prevention of the religious-political extremism and terrorism includes:

- the definition of the content and relationships of basic concepts (violence, religious-political extremism, terrorism, counteraction to religiouspolitical extremism and terrorism, the prevention of religious-political extremism and terrorism, etc.);

- the preventing of the religious-political extremism and terrorism as a complex scientific problem. The system analysis of the prevention of the religious-political extremism and terrorism as a kind of social activity;

- the interpretation of the prevention of the religious-political extremism and terrorism as the most important segments of the proactive system response (reaction) of modern society to emerging global threats;

- the study of basic foundations and features of the ideology of the religious-political extremism and terrorism;

- the development of conceptual principles and bases of anti-terrorist and anti-extremist ideology;

- the research and study the mechanisms of formation of motivation of the anti-terrorist and antiextremist behavior of citizens of the Republic of Uzbekistan, especially in the regions, where there is the influence of extremist views and beliefs;

- the development of conceptual principles and bases of forming in the public consciousness a negative image of extremists and terrorists;

- the development of conceptual principles and bases of formation in public consciousness a positive image of fighter against extremism and terror;

- the development of methods and techniques of the combating with ideological support for extremism and terrorism;

- the study of the causes, factors and conditions conducive to the involvement of citizens in extremist and terrorist activity;

- the comparative analysis of the experiences of different countries on preventing religious-political extremism and terrorism and development of recommendations on using this experience in the Republic of Uzbekistan;
- the study on outreach of technologies that use the ideology of the religious-political extremism and terrorism to spread their views;

- the study of the religious extremism in comparative perspective of the past and present;

- the studying of the religious extremism and fundamentalism;

- the study of the religious-political extremism and terrorism in a multi-ethnic society;

- the development of scientific-methodological base to expose the false stereotypes in the public mind about the relationship of the traditional religions and the religious-political extremism and terrorism.

In this case we must consider some psychological bases and social-psychological techniques of prevention of terrorism. They are:

- the study of the religious-political extremism and terrorism as psychological phenomena and discovering their psychological nature, forms, types and levels of manifestation;

- the study, classification of the causes and factors contributing to the involvement of representatives of different age and social groups in extremist, terrorist organizations and the spread of the ideology of the religious-political extremism and terrorism;

- the research and identification of personal characteristics associated with the risk of formation of the terrorist stereotypes and tolerance in relation to the phenomena of the religious-political extremism and terrorism;

- the development and testing of the complex of psychological diagnostic techniques to identify groups at risk to the effects of the religious-political extremism and terrorism;

- the study of risk factors of spreading the ideology of the religious-political extremism and terrorism among adolescents and youth and development of the psycho-pedagogical technologies of prevention of their involvement in the extremist and terrorist organizations;

- the development of methods of psychological examination of publications in mass media, including the Internet, educational and methodical literature on the presence of signs promoting the ideology of religious-political extremism and terrorism and to justify the extremist and terrorist activity;

- the development and validation of social and psychological technologies to counter the ideology of the religious-political extremism and terrorism in the mass-media and in educational institutions of the general and higher education.

In the focus of our attention are the pedagogical bases for the prevention of the religious and political extremism and terrorism. Among them we would like to consider some of them.

1. The formation of educational-methodical and normative base for the opening of several new 
humanitarian specialties of the higher professional education on the problem of preventing of the religious-political extremism and terrorism.

2. The development of training-methodical bases of forming anti-extremist, anti-terrorist consciousness of students in the higher education institutions.

3. The development and substantiation of recommendations for teachers of secondary schools and colleges by "embedding" in the educational process of elements anti-extremist and anti-terrorist ideology.

4. The research and identify the causes of extremist sentiment caused by deficiencies in the system of humanitarian education and upbringing, including the teaching of falsified history.

5. The development and substantiation of methodical recommendations for the prevention of group conflicts on the ethnic and religious basis in collectives of various types (high school, universities, military, employment, etc.).

There are also the cultural bases of the preventing of the religious-political extremism and terrorism.

1. The research and identify the causes of the extremist sentiment caused by the loss of ideals and system of values and ideological orientation of the entire social strata of society.

2. The research and identify the causes of the extremism due to religious differences, including on the basis of artificially created doctrinal and ideological differences between Islam and Christianity.

3. The research and identification of the causes and conditions of formation and distribution of extremist moods, caused by ethnic conflicts and prejudices, as well as purposefully carried out by external influences.

4. The research and identify the causes of the extremist sentiment caused by ignoring of the mental and cultural traditions and peculiarities of individual populations.

5. The development and validation of the proposals for more effective impact of culture on the development of dialogue of religions.

6. The development of methods of forming a youth anti-extremist and anti-terrorist positions, including the questions of the equality of national cultures and religions.

7. The interlingual and intercultural communication as a means of combating to the xenophobia and religious-political extremism and terrorism.

The using of information and communication technologies in preventing of the religious-political extremism and terrorism also play a main role. In this sphere are more important processes as:

1. Development and validation of detection mechanisms in the information space of the country materials with signs of propaganda of the extremist and terrorist ideology.

2. The development of effective methods of counteraction to information resources of extremist and terrorist orientation in computer networks.

3. The development and implementation of new mathematical models and information technologies to improve the efficiency of monitoring the electronic mass-media to identify the content of the extremist and terrorist orientation.

4. The development and validation of new information and communication tools enabling the identification of the target audience the information resources of extremist and terrorist orientation.

The process of the religious revival is one of the most important global trends of social development of the Muslim countries in the late XX - early XXI centuries. In modern conditions, the role of Islam as a global political factor and a special place in this process is a radical Sunni ideology, manifested in the process of Islamic revival in some Muslim countries and regions.

The specific experience of the religiouspolitical extremist interpretation of the ideological doctrines of Islam, its ambiguous ideological and spiritual influence in the Muslim world, political impact on the situation in various, often non-Muslim countries and regions, a special role in international relations in general is a unique phenomenon. A powerful political potential of the religious-political extremism, which has a direct impact on religious and legal institutions of the respective countries and regions, the practice of missionary expansionism, increasingly aggressive nature. The scope of this process and the participation of various states and peoples are doing the modern religious-political extremism influential entity not only regional, but also world politics.

\section{References:}




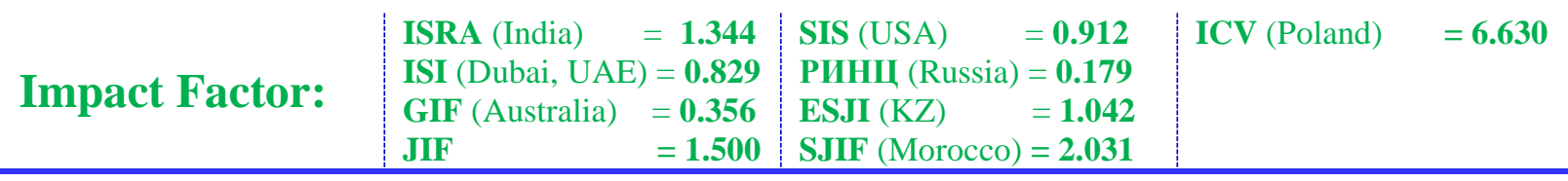

1. Abdulatipov RG (2002) Problemy profilaktiki jekstremizma // Jetnopanorama, 2002, №2 pp.74.

2. Antonjan JM (2010) Jekstremizm i ego prichiny / Ju.M. Antonjan.- Moscow: Logos, 2010. - 288 p.- ISBN: 978-5-98704-502-2.

3. (2010) Informacionno-metodicheskij bjulleten' KROO «ISTOK», vyp. 1(3) «Tolerantnost'», 2009-2010

4. Karimov IA (1997) Uzbekistan na poroge XXI veka: Ugrozy bezopasnosti, uslovija i garantii progressa. -T.: Y̆zbekiston. 1997. 315 p.

5. Kozlov AA (2009) Molodezhnyj jekstremizm. $\mathrm{SPb}, 2009$.

6. Perepelkin GE (2009) Molodezhnyj jekstremizm kak ugroza obshhestvennoj bezopasnosti // Pravovaja kul'tura. - Saratov:
Izd-vo Sarat. jurid. in-ta MVD Rossii, 2009, № 1 (6). - pp. 147-155.

7. Ponomarev VA (1989) Islam v Uzbekistane, 1989-1995 gg.// «Politicheskie issledovanija». 1996. №2.

8. Rozhkov MI, et al. (2012) Vospitanie tolerantnosti u shkol'nikov. Jaroslavl', 2012.

9. Sazanova E (2008) Molodezhnyj jekstremizm kak social'nyj fenomen // Jekstremizm i drugie kriminal'nye javlenija. - M.: Rossijskaja kriminologicheskaja associacija, 2008. - pp. 4346.

10. Trofimov D (1997) Islamskij faktor i problemy vnutrennej stabil'nosti v Central'noj Azii // V bjulletene RAI IVAN Ross.AN. 1997. №1(55). -M.: pp. 92-103.

11. Shegorcov AA (2009) Kak rozhdaetsja jekstremizm molodezhi. Moscow, 2009. 